\title{
Regulation of nitrification in the land-ocean contact area of the Rhône River plume (NW Mediterranean)
}

\author{
Micheline Bianchi ${ }^{1, *}$, Feliatra $^{1}$, Dominique Lefevre ${ }^{2}$ \\ ${ }^{1}$ Laboratoire de Microbiologie Marine CNRS/INSU UPR 223, Université de la Méditerranée, Campus de Luminy Case 907, \\ F-13288 Marseille Cedex 9, France \\ ${ }^{2}$ Laboratoire d'Océanologie et de Biogéochimie CNRS/INSU UMR 6535, Université de la Méditerranée, Campus de Luminy \\ Case 901, F-13288 Marseille Cedex 9, France
}

\begin{abstract}
The study of natural conditions controlling nitrification processes was undertaken in the estuarine area of the Rhône River (NW Mediterranean Sea) over an annual cycle. Nitrification rates (Noxidation rates, $\mathrm{CO}_{2}$ fixation rates, specific counts of ammonium and nitrite oxidisers) as well as environmental parameters (temperature, salinity, suspended matter, inorganic nitrogen) were measured monthly over a 1 yr period. Depth profiles were obtained in low salinity plume water, at the edge of the plume (intermediate salinity) and in the sea, to study the evolution of nitrification processes from the mouth of the river to the sea of both the brackish surface layer and the bottom nepheloid layer. Nitrification rates in the surface plume gerierally declined with distance from the river and with increasing salinity, whereas nitrification rates in the benthic nepheloid layer exhibited little spatial variation. This was

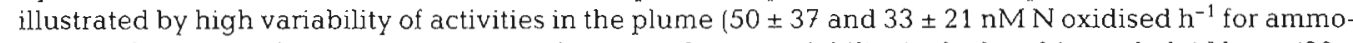
nium and nitrite oxidation rates respectively) versus lower variability in the benthic nepheloid layer ( $30 \pm$ 8 and $22 \pm 6 \mathrm{nM} \mathrm{N}$ oxidised $\mathrm{h}^{-1}$ for ammonium and nitrite oxidation rates respectively). Nitrification rates in both the plume and benthic nepheloid layer were higher in the summer (142 to $175 \mathrm{nM} \mathrm{N}$ oxidised $\mathrm{h}^{-1}$ for ammonium oxidation and 64 to $96 \mathrm{nM} \mathrm{N}$ oxidised $\mathrm{h}^{-1}$ for nitrite oxidation) than during the winter months ( 5 to $30 \mathrm{nM}$ oxidised $\mathrm{h}^{-1}$ for both activities). Highest $\mathrm{N}$-oxidation rates were related to low salinity in the surface layer, corresponding to the highest concentrations of ammonium from the river water. Ammonium oxidation $(\mathrm{AO})$ is regulated by in situ ammonium concentration $\left(\mathrm{r}^{2}=0.741, \mathrm{p}=\right.$ $0.0001, \mathrm{n}=132)$ and nitrite oxidation (NO) by the ammonium oxidation rate $\left(\mathrm{r}^{2}=0.850, \mathrm{p}=0.0001, \mathrm{n}=\right.$ 132). AO rate $=14.5+10\left[\mathrm{NH}_{4}{ }^{+}\right]$and $\mathrm{NO}$ rate $=4.7+0.56 \mathrm{AO}$ rate. $Q_{10}$ values were calculated for am-

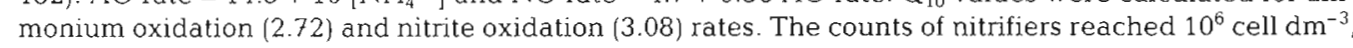
representing less than $2 \%$ of the total bacterial counts. Nitrogen oxidation rates were correlated to nitrifying cell abundances $\left(r=0.89\right.$ to 0.99 ), and the activities per cell ranged from 1.2 to $1.9 \times 10^{-15} \mathrm{~mol} \mathrm{~N}$ oxidised cell $\mathrm{l}^{-1} \mathrm{~d}^{-1}$. The biomass production of the ammonium oxidisers was demonstrated by the decrease of $\mathrm{N}$ oxidised/C fixed ratio from $15.8 \mathrm{in}$ winter to $10.8 \mathrm{in}$ summer, in spite of the increase of AO rate in summer. A seasonal fluctuation of $\mathrm{N}$ oxidised/C fixed ratio for nitrite oxidisers was not demonstrated; however, the ratio increased from $21.8 \pm 4.4$ in winter to $29.3 \pm 2.9$ in summer. We estimated that $10 \%$ (winter) and $20 \%$ (summer) of ammonium was nitrified at the mouth of the river. During summer, nitrification is supported by the flux of ammonium from in situ mineralisation and contributes to nitrate excess in the plume. The contribution of nitrification to the $\mathrm{N}$ requirement of the primary producers was estimated to be $14 \%$ at the edge of the plume (intermediate salinity) and $66 \%$ at the sea station.
\end{abstract}

KEY WORDS: Nitrification rates - Mediterranean Sea $\cdot$ Plume - Seasonal cycle - Ammonium oxidisers · Nitrite oxidisers

\section{INTRODUCTION}

The understanding and further modelling of the impact of terrestrial inputs on the functioning of the

\footnotetext{
•E-mail: m-bianchi@luminy.univ-mrs.fr
}

marine ecosystem, and more precisely on the functioning of the marine areas affected by the estuaries, depend on our capability to identify and classify the main factors regulating the bacterially mediated processes. Within the numerous processes involved in the functioning of ecosystems, nitrifiers play a central role in oxidising the more reduced form of nitrogen $\left(\mathrm{NH}_{4}{ }^{+}\right)$ 
into more oxidised forms, including $\mathrm{NO}_{2}^{-}$and $\mathrm{NO}_{3}{ }^{-}$. Estuaries receive, via river discharge, dissolved and particulate organic and inorganic inputs that provide nitrogen and hold specific bacterial species. Spatial fluctuations of estuarine nitrification have been demonstrated through changes in the distribution and concentration of the different forms of inorganic nitrogen (Berounsky \& Nixon 1990, Bronk \& Glibert 1993. Pakulski et al. 1995). Nitrification rates have also been measured along the plume salinity gradient in several estuaries (Elkins et al, 1981, Helder \& de Vries 1983, Owens 1986, Feliatra \& Bianchi 1993).

The principal factors (substrate availability, temperature, oxygen, $\mathrm{pH}$, light and substratum) regulating nitrifying activities have been described for pure cultures and for soil environments (Johnstone \& Jones 1988, Guerrero \& Jones 1997). The difficulty in extrapolating the response of pure cultures to the natural environment is however illustrated by the discrepancy between values of half-saturation constants of ammonium oxidisers in pure culture compared to those measured in the natural environment. Kaplan (1983) demonstrated that substrate affinity coefficients for marine nitrifying bacteria are much lower in in situ conditions than in culture conditions. For pure cultures, Prosser (1989) measured Km (affinity constant) values ranging from 0.051 to $14 \mathrm{mM}$ while Gentilhomme (1992) estimated $\mathrm{Km}$ values of $0.017 \mu \mathrm{M}$ in the Southwestern Mediterranean Sea. Relatively little attention has been paid to the relationships between apparent regulatory factors and in situ nitrifying rates. The predominant role of temperature on nitrification rates was demonstrated with in situ measurements during an annual cycle in Narragansett Bay, USA, by Berounsky \& Nixon (1990). These authors estimated very high $Q_{10}$ values for nitrification $(6.8$ to 17.6$)$ in contrast to values of 2 to 3 measured for this activity by Carlucci \& Strickland (1968) and Helder \& de Vries (1983).

The Rhône River estuary is located in the northern part of the Western Mediterranean Sea. With an average flow of $1700 \mathrm{~m}^{3} \mathrm{~s}^{-1}$, the Rhone discharges $5 \times 10^{6} \mathrm{t}$ $\mathrm{yr}^{-1}$ of particulate matter, $76600 \mathrm{t} \mathrm{yr}^{-1}$ of inorganic nitrogen, $8400 \mathrm{t} \mathrm{yr}^{-1}$ of phosphorus and $92000 \mathrm{t} \mathrm{yr}^{-1}$ of silicate into the Northern Mediterranean Sea (Coste et al. 1985). The highest Rhône River outflows typically occur in spring and autumn and the lowest at the end of summer and in mid-winter. At the same time, nitrate displays maximum concentrations in winter and minimum in summer, while ammonium concentrations, coupled with dissolved organic nitrogen, are maximal in summer and autumn (Coste 1993). Due to the combination of light (controlled by the particulate load) and nutrient availability (controlled by nutrient concentrations), primary production at the plume boundary is 10 times the primary production within the plume and 7 times greater than primary production in the oligotrophic marine area (Videau \& Leveau 1990. Minas \& Minas 1989). This localisation is similar to that noted in the Mississippi River plume (Lohrenz et al 1990). At the same time, in the plume area, due to enrichments of ammonium and nitrate, bacterial processes such as nitrification, denitrification and nitrate reduction occur simultaneously (Bianchi et al. 1994).

The opportunity to look at the control of nitrifying activities in a natural environment was given, in the present work, by an annual cycle of measurements in the estuary of the Rhône River. The plume area provides highly variable conditions (salinity, inorganic nitrogen, organic carbon and suspended matter). The effect of these environmental parameters was estimated on nitrifying activitics measured as $\mathrm{N}$-oxidation rates, ${ }^{14} \mathrm{C}_{-} \mathrm{CO}_{2}$ fixation rates and nitrifying bacteria counts. Furthermore, the importance of nitrification on the estuarine ecosystem could be assessed through studying the relationships between nitrifying activities and environmental factors.

\section{MATERIAL AND METHODS}

Sampling site and strategy. The 3 sampling stations were located in the vicinity of the Rhône River plume (Fig. 1), in the Northwestern basin of the Mediterranean Sea. Samples were taken monthly from November 1991 until October 1992. Following the hydrological structure of this area (see description in Feliatra $\&$ Bianchi 1993) we sampled 4 depths at each station: surface (plume), $1.5 \mathrm{~m}, 10 \mathrm{~m}$ and $2 \mathrm{~m}$ above the sediment (bottom nepheloid). The depth of the bottom increased from $50 \mathrm{~m}$ at the proximal station to an average of $200 \mathrm{~m}$ at the distal station. Water samples were collected using an 81 Niskin bottle. All parameters were measured at each depth. Specific counts of nitrifying bacteria and the incorporation of ${ }^{14} \mathrm{CO}_{2}$ by nitrifiers were determined only once per season (January, May, July, October).

Physical and chemical parameters. Salinity and temperature were measured using a YSI 33 CTD probe (Yellow Springs Instrument Co, Yellow Springs, Ohio, USA). At each depth, subsamples were obtained for measurements of total suspended matter (Strickland \& Parsons 1972), $\mathrm{NH}_{4}{ }^{+}$(Solorzano 1969), $\mathrm{NO}_{2}^{-}$(Bendschneider \& Robinson 1952), and for $\mathrm{NO}_{3}{ }^{-}$determination by Technicon Analyzer (Tréguer \& Le Corre 1975). Particulate carbon and nitrogen were measured with a CHN analyser (Perkin Elmer $204 \mathrm{C}$ ), using GF/F Whatman ${ }^{\otimes}$ filters combusted at $400^{\circ} \mathrm{C}$ for $4 \mathrm{~h}$, and fumed with $\mathrm{HCl}$ prior to analysis.

Bacteriological parameters. Total bacterial counts were performed on samples ( 2 to $5 \mathrm{~cm}^{3}$ ) filtered on 
$0.2 \mu \mathrm{m}$ black Nuclepore filters following DAPI staining (Porter \& Feig 1980), using an image analysis system (Van Wambeke 1988). Abundances of culturable ammonium oxidisers and nitrite oxidisers were estimated by the most probable number (MPN) technique (Tanaka et al. 1979). The mineral medium was amended with $\left(\mathrm{NH}_{4}\right)_{2} \mathrm{SO}_{4}\left(200 \mathrm{mg} \mathrm{dm}^{-3}\right)$ for ammonium oxidisers and $\mathrm{NaNO}_{2}\left(100 \mathrm{mg} \mathrm{dm}{ }^{-3}\right)$ for nitrite oxidisers. For each dilution, 1 to $10^{-7}, 2 \mathrm{~cm}^{3}$ of sample was inoculated into $18 \mathrm{~cm}^{3}$ of culture medium and incubated in the dark at $25^{\circ} \mathrm{C}$ for 22 and $49 \mathrm{~d}$ for ammonium and nitrite oxidisers respectively. The growth of ammonium oxidisers was indicated by the presence of nitrite in the medium as demonstrated by the Griess reagent Prolabo ${ }^{w}$ and the growth of nitrite oxidisers by the disappearance of nitrite and presence of nitrate (reagent with diphenylamine). A statistical calculation of the MPN was performed (Rand et al. 1979).

Nitrification rates were determined as described by Feliatra \& Bianchi (1993). Changes in nitrite concentration were measured in sub-samples containing allylthiourea (ATU) or $\mathrm{NaClO}_{3}$ in order to inhibit the oxidation of ammonium and nitrite respectively. The sample was divided into $3 \times 1 \mathrm{dm}^{3}$ sub-samples. One (blank) was unamended, one received $10 \mathrm{mg} \mathrm{ATU} \mathrm{dm}^{-3}$ (final concentration) and the third received $10 \mathrm{mM}$ (final concentration) $\mathrm{NaClO}_{3}$. No substrate was added. The sub-samples were incubated in the dark in a culture chamber at in situ temperature $\left(15^{\circ} \mathrm{C}\right)$. The nitrite concentration in the sub-samples was measured (Bendschneider \& Robinson 1952) over 24 h at 4 h intervals, using $10 \mathrm{~cm}$ pathlength cells. The nitrification rates were derived from the linear relationship between the increase (ammonium oxidation: $\mathrm{AO}$ ) or decrease (nitrite oxidation: $\mathrm{NO}$ ) in nitrite concentration and time. In such short-term incubations, the effectiveness of inhibition with ATU treatment has been demonstrated for up $2.5 \mathrm{~d}$ of incubation (Hall 1984).

The ${ }^{14} \mathrm{C}-\mathrm{CO}_{2}$ dark incorporation by nitrifiers was measured by the difference in $\mathrm{H}^{14} \mathrm{CO}_{3}{ }^{-}$incorporated between samples with and without the addition of the inhibitors ATU and $\mathrm{NaClO}_{3}$ (Somville 1984). Each sample was divided into $6 \times 100 \mathrm{~cm}^{3}$ sub-samples: 2 unamended blanks, 2 amended with $10 \mathrm{mg}$ ATU $\mathrm{dm}^{-3}$, and 2 amended with $10 \mathrm{mM} \mathrm{NaClO}$. $\mathrm{NaH}^{14} \mathrm{CO}_{3}(5 \mu \mathrm{Ci}$ [185 $\mathrm{KBq}]$ Amersham, specific activity $51.8 \mathrm{mCi}$ $\mathrm{mmol}^{-1}=1.92 \mathrm{GBq} \mathrm{mmol}^{-1}$ ) was added to every subsample. The bottles were incubated in a culture room at in situ temperature for $4 \mathrm{~h}$. At the end of the incubation the samples were filtered through a $0.2 \mu \mathrm{m}$ Nuclepore filter. The filters were rinsed with filtered sea water and $0.5 \mathrm{~N} \mathrm{HCl}$ in order to remove any unincorporated ${ }^{14} \mathrm{C}$ and counted on a Beckman model LS 1800. The amount of $\mathrm{C}$ incorporated due to nitrification was

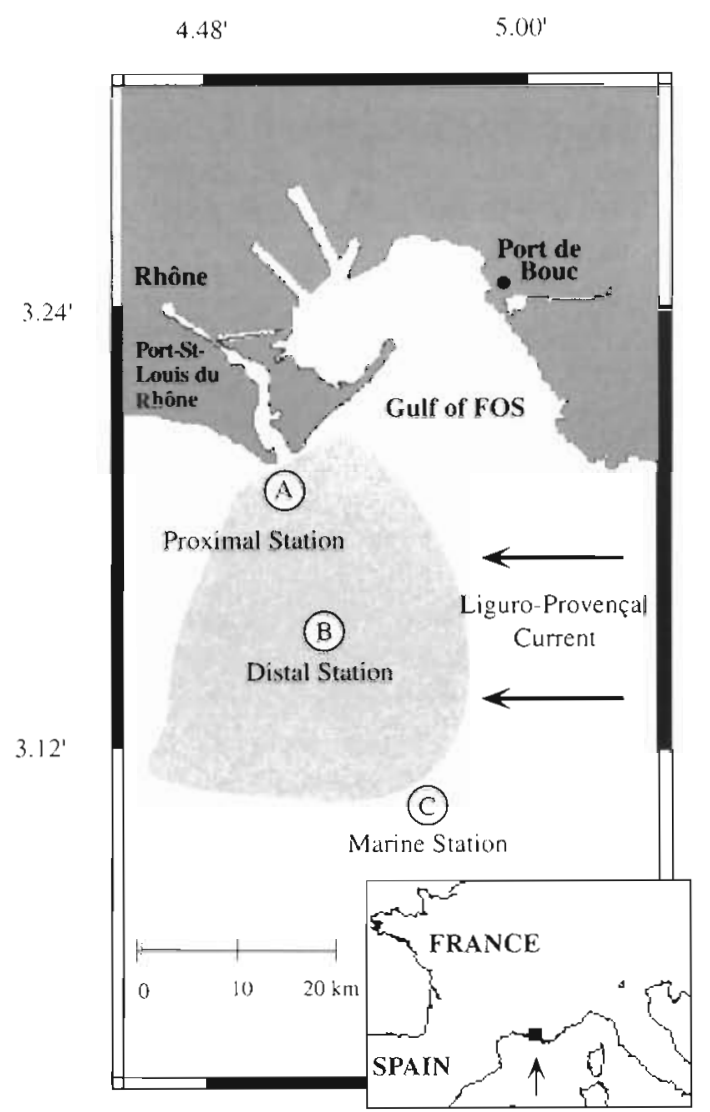

Fig. 1 Location of sampling stations. The shaded area shows the plume extension

calculated as the difference between the amount of ${ }^{14} \mathrm{C}$ activity in samples with and without ATU for the ammonium oxidisers and in samples with and without chlorate for the nitrite oxidisers. Previous tests have demonstrated the optimal incubation time for carbonate incorporation is $4 \mathrm{~h}$ as incubations of 12 or $24 \mathrm{~h}$ resulted in lower amounts of carbon incorporation due to losses of respiratory and excretory carbon and recycling processes (Feliatra 1994).

\section{RESULTS}

\section{Environmental characteristics}

Typical salinity depth profiles for each station are presented in Fig. 2. Throughout the year, the proximal station exhibited a low salinity upper layer of $1.5 \mathrm{~m}$ and a strong increasing gradient of salinity between $1.5 \mathrm{~m}$ and $10 \mathrm{~m}$. This gradient was still present but attenuated at the distal station while at the sea station the influence of river water was no longer detected (Fig. 2). For this distribution of salinity, no annual cycle was observed. 


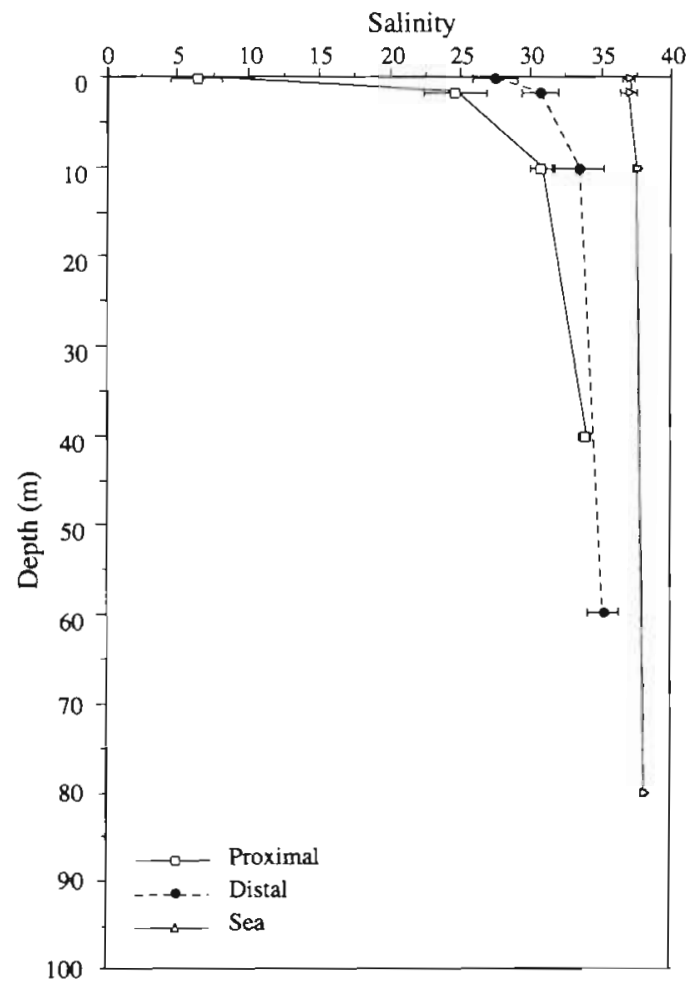

Fig. 2. Typical depth profiles of salinity at the proximal, distal and sea stations

Water temperatures fluctuated from $10^{\circ} \mathrm{C}$ in winter to $18^{\circ} \mathrm{C}$ in summer. In winter, temperature globally increased from the plume water $\left(11.2^{\circ} \mathrm{C}\right)$ to the sea water $\left(12.0^{\circ} \mathrm{C}\right)$, while it was the reverse situation in summer (i.e. $17.7^{\circ} \mathrm{C}$ for plume water and $15.3^{\circ} \mathrm{C}$ for sea

Table 1. Seasonal average values $( \pm \mathrm{SD})$ of temperature $\left({ }^{\circ} \mathrm{C}\right)$ at the 3 stations. Winter, spring and autumn: $n=12$; summer: $n=8$

\begin{tabular}{|c|c|c|c|}
\hline Season & Proximal & Distal & Sea \\
\hline Winter & $11.2 \pm 1$ & $11.2 \pm 0.9$ & $12.0 \pm 0.2$ \\
\hline Spring & $13.7 \pm 0.3$ & $13.5 \pm 0.3$ & $13.7 \pm 0.2$ \\
\hline Summer & $17.7 \pm 0.5$ & $16.7 \pm 1.6$ & $15.3 \pm 1.9$ \\
\hline Autumn & $16.9 \pm 0.8$ & $16.2 \pm 1.8$ & $15.3 \pm 1.9$ \\
\hline
\end{tabular}

water). At the distal and the sea stations, a vertical gradient was observed in summer and autumn, demonstrated by an increased value of the SD of the average temperature (Table 1). The fluctuations of the suspended matter (SM) load demonstrated 2 trends: (1) at the proximal station, all depths showed a similar weight of suspended matter (34 to $39 \mathrm{mg} \mathrm{dm}^{-3}$ ) with non-seasonal variations, (2) at the 2 other stations, the bottom nepheloid layer demonstrated a SM load higher than those of the other depths, particularly the surface layer. The SM load of the surface layer exhibited a seasonal trend with an increase in spring and summer, a decrease in autumn, and low values in winter (Table 2). The load of SM in the bottom nepheloid layer did not decrease with increasing distance from the mouth of the river

Particulate organic carbon (POC) fluctuations displayed different patterns (Table 2). In the surface layer the POC showed a drastic drop (70\%) between the proximal and the sea stations, while the SM decreased by only $40 \%$. The values of the POC/PON ratio in the surface layer and at $1.5 \mathrm{~m}$ depth of the sea station were significantly lower than those of the proximal and the distal stations ( $t$-test, $\mathrm{df}=20, \mathrm{p}=0.05$ ), indicating the detrital composition of the particles in the plume water. In the bottom nepheloid layer, POC decreased by about $30 \%$ and the POC/PON ratio remained close to 11. The combination of the characteristics of SM, POC and $\mathrm{C} / \mathrm{N}$ suggested an uncoupling of the bottom nepheloid layer from the water column.

The distinction between the surface water and the bottom nepheloid layer was confirmed by the concentrations of ammonium, nitrite and nitrate (Fig. 3). In the bottom nepheloid layer, concentrations of inorganic nitrogen forms were very similar and did not fluctuate during the year at the 3 stations, whereas concentrations of ammonium, nitrite and nitrate decreased from the proximal station to the sea in the superficial layer (Fig. 3). In the surface layer, nitrite and nitrate distribution exhibited the same pattern at the 3 stations despite a 3-fold increase between sea and distal stations and again a 3 -fold increase between distal and proximal stations. Nitrite concentrations peaked in summer whereas nitrate peaked in winter and sum-

Table 2. Annual average values ( $\pm \mathrm{SD}$ ) of suspended matter (SM), particulate organic carbon (POC) and $\mathrm{C} / \mathrm{N}$ ratio of the particulate matter at the 3 stations $(\mathrm{n}=11$ )

\begin{tabular}{|c|c|c|c|c|c|c|c|c|c|}
\hline & \multicolumn{3}{|c|}{$\mathrm{SM}\left(\mathrm{mg} \mathrm{dm}^{-3}\right)$} & \multicolumn{3}{|c|}{$\mathrm{POC}\left(\mathrm{mg} \mathrm{dm} \mathrm{m}^{-3}\right)$} & \multicolumn{3}{|c|}{$\mathrm{C} / \mathrm{N}$ ratio } \\
\hline & Proximal & Distal & Sea & Proximal & Distal & Sea & Proximal & Distal & Sea \\
\hline Surface & $37.4 \pm 3.9$ & $26.3 \pm 6.8$ & $22.6 \pm 8.0$ & $1.44 \pm 1.03$ & $0.74 \pm 0.24$ & $0.42 \pm 0.19$ & $12.6 \pm 4.2$ & $12.1 \pm 5.2$ & $9.7 \pm 2.5$ \\
\hline $1.5 \mathrm{~m}$ & $35.7 \pm 3.3$ & $32.5 \pm 5.4$ & $28.4 \pm 2.9$ & $0.80 \pm 0.35$ & $0.49 \pm 0.23$ & $0.31 \pm 0.05$ & $12.9 \pm 2.6$ & $9.4 \pm 3.2$ & $9.6 \pm 2.5$ \\
\hline $10 \mathrm{~m}$ & $34.1 \pm 4.1$ & $32.2 \pm 4.4$ & $31.0 \pm 4.4$ & $0.49 \pm 0.29$ & $0.43 \pm 0.17$ & $0.28 \pm 0.10$ & $10.0 \pm 2.0$ & $9.9 \pm 1.9$ & $10.4 \pm 3.3$ \\
\hline Bottom & $38.9 \pm 4.5$ & $38.4 \pm 5.0$ & $37.0 \pm 5.4$ & $0.67 \pm 0.48$ & $0.35 \pm 0.22$ & $0.46 \pm 0.25$ & $10.9 \pm 4.1$ & $11.3 \pm 2.9$ & $10.6 \pm 2.3$ \\
\hline
\end{tabular}



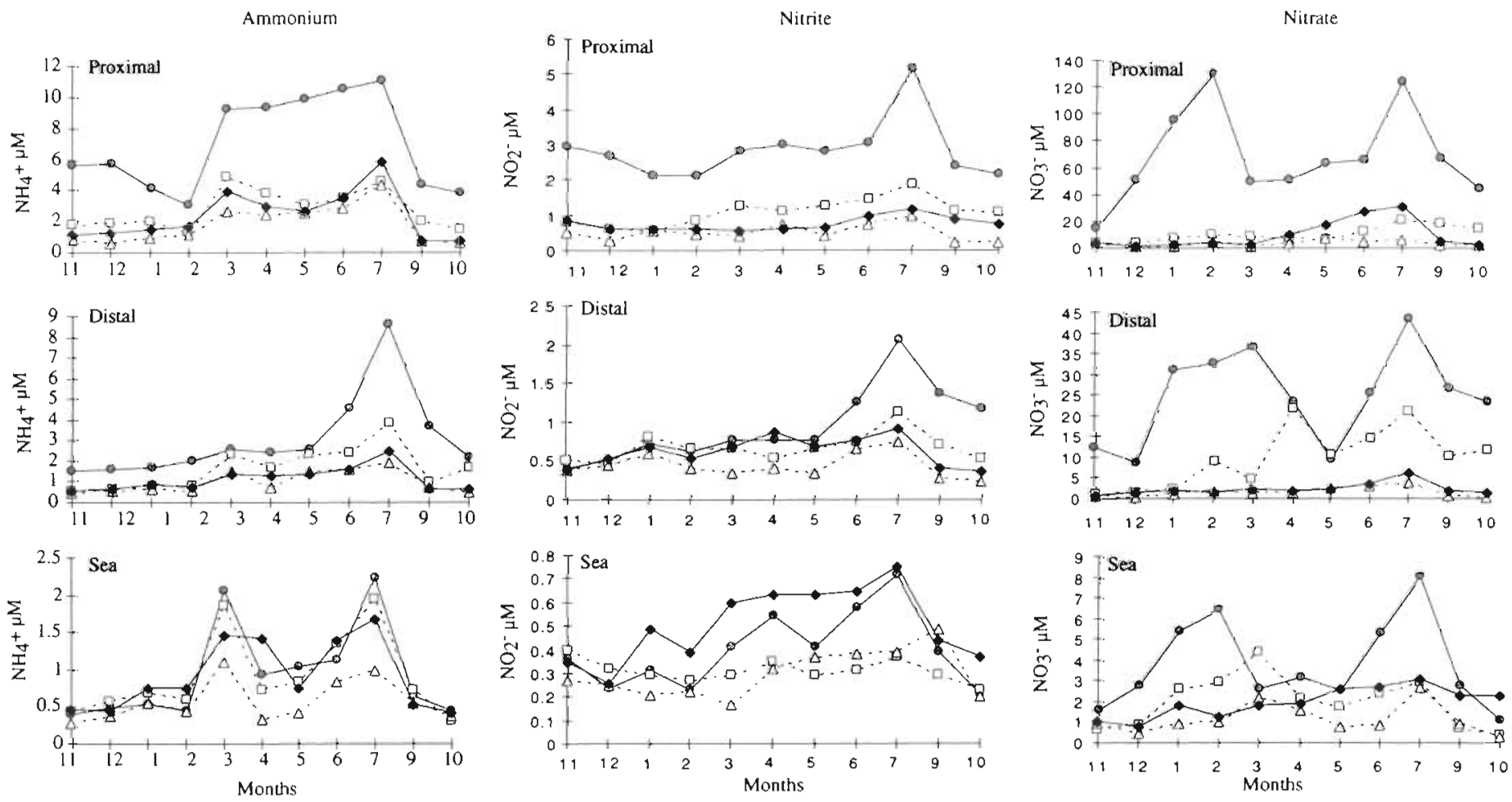

$\rightarrow$ Surface $\quad \cdots \square \cdot 1.5 \mathrm{~m} \quad \cdots \Delta \cdot 10 \mathrm{~m} \quad \longrightarrow$ Bottom

Fig. 3. Seasonal fluctuations of inorganic nitrogen species

mer. Ammonium distribution exhibited a different pattern at the 3 stations, with a late winter and a summer peak at the sea station, a single summer peak at the distal station, and high concentrations from late winter to late summer at the proximal station. There was a 3 fold increase between open sea and distal stations and an 1.5-fold increase between distal and proximal stations.

\section{Bacterial counts}

In the surface layer, total bacterial numbers decreased from the plume to the sea, while they were quite similar in the bottom nepheloid layer (Fig. 4). For all samples the number of bacteria fluctuated in a narrow range ( 5 to $6 \times 10^{6}$ bacteria $\mathrm{cm}^{-3}$ ). A seasonal effect on total counts of bacteria could be demonstrated in the surface layer (surface and $1.5 \mathrm{~m}$ ), with highest numbers in May and July (Fig. 4) and a trend to decrease from July to January. In winter, the bacterial abundance was similar at all stations. The number of culturable ammonium oxidisers fluctuated from 1.1 (winter, sea station, $10 \mathrm{~m}$ depth) to $35 \times 10^{3}$ bacteria $\mathrm{cm}^{-3}$ (summer, proximal station, surface layer). Abundance of culturable nitrite oxidisers was 3 to 5 times lower than that of ammonium oxidisers (Fig. 4). As with total numbers of bacteria, numbers of nitrifiers decreased both from the proximal to the sea station and from July to January.

\section{Distribution of nitrification activity}

In the study area, nitrification displayed 3 major characteristics (Fig. 5). (1) The upper layers (surface and $1.5 \mathrm{~m}$ ) demonstrated a behaviour different from the $10 \mathrm{~m}$ and bottom nepheloid layers. In the deepest layers, whatever the sampling station, the nitrifying rates were similar, while in the surface layers 0 and $1.5 \mathrm{~m}$ ) there was a decreasing gradient of both rates from the proximal to the sea station. (2) At the sea station, the nitrifying rates were higher in the bottom nepheloid and $10 \mathrm{~m}$ depth layers than in the upper layers. (3) At all depths, the nitrifying rates exhibited seasonal trends with the lowest values in January-February ( 5 to $30 \mathrm{nM} \mathrm{N}$ oxidised $\mathrm{h}^{-1}$ for both activities) and the highest in July (between 142 and $175 \mathrm{nM} \mathrm{N}$ oxidised $\mathrm{h}^{-1}$ for $\mathrm{AO}$ and 64 to $96 \mathrm{nMN}$ oxidised $\mathrm{h}^{-1}$ for $\mathrm{NO}$ at the distal and proximal stations, respectively).

As for the $\mathrm{N}$ oxidation rates, the $\mathrm{CO}_{2}$ incorporated by the nitrifiers decreased from the proximal to the sea 


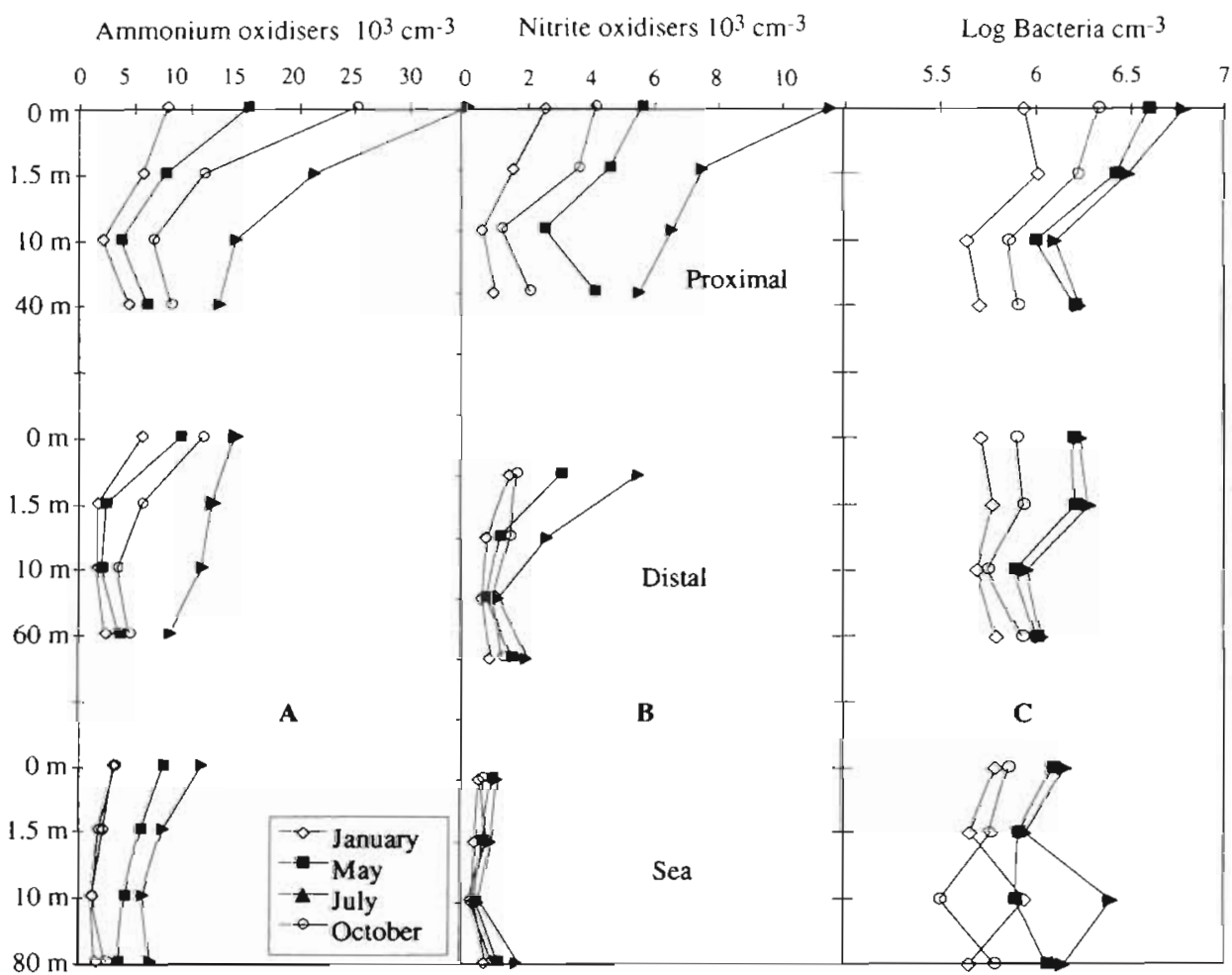

Fig. 4. Spatio-temporal fluctuations of (A) ammonium oxidiser, (B) nitrite oxidiser (C) and total bacteria counts

Table 3 . Seasonal average values $( \pm \mathrm{SD}, n=4)$ of $N$ oxidised to $\mathrm{C}$ incorporated ratio at the 3 stations

\begin{tabular}{|lcccccc}
\hline Season & \multicolumn{3}{c}{$\begin{array}{c}\text { Ammonium oxidisers } \\
\text { Distal }\end{array}$} & Sea & Proximal & $\begin{array}{c}\text { Nitrite oxidisers } \\
\text { Distal }\end{array}$ \\
\hline Winter & $15.2 \pm 1.5$ & $14.3 \pm 2.7$ & $16.1 \pm 2.3$ & $23.5 \pm 6.2$ & $22.4 \pm 2.7$ & $19.7 \pm 4.5$ \\
Spring & $13.5 \pm 0.1$ & $14.1 \pm 0.3$ & $14.2 \pm 2.3$ & $29.3 \pm 0.1$ & $29.0 \pm 0.3$ & $26.1 \pm 6.0$ \\
Summer & $10.4 \pm 0.1$ & $11.0 \pm 0.3$ & $10.9 \pm 0.1$ & $32.4 \pm 1.0$ & $26.7 \pm 7.6$ & $30.6 \pm 0.3$ \\
Autumn & $13.0 \pm 0.2$ & $13.4 \pm 0.1$ & $13.5 \pm 0.2$ & $29.4 \pm 0.3$ & $28.8 \pm 0.6$ & $28.7 \pm 0.2$ \\
\hline
\end{tabular}

station in the surface and $1.5 \mathrm{~m}$ layers, while the rates were similar in the $10 \mathrm{~m}$ depth and bottom nepheloid layers (Fig. 6). Seasonal fluctuations were demonstrated at the proximal and distal stations. At the sea station, the rates of $\mathrm{CO}_{2}$ incorporation were low and only the summer rates (July) increased clearly (Fig. 6).

The molar ratio of nitrogen oxidised per carbon incorporated was measured 4 times during the year at

Table 4. Relationships (Spearman coefficient) between nitrifying activities and environmental factors $(n=132) . \cdots p \leq$ $0.001_{i}$ ns: non significant. AOR: ammonium oxidation rate; NOR: nitrite oxidation rate; SM: suspended matter

\begin{tabular}{|cccccc|} 
& Month & Station & Depth & Salinity & SM \\
\hline AOR & ns & $0.14 \cdots$ & $0.1 \cdots$ & $0.34 \cdots$ & $0.11 \cdots$ \\
NOR & ns & $0.14 \cdots$ & ns & $0.27 \cdots$ & ns \\
\hline
\end{tabular}

all stations. This ratio trended to decrease in summer. The average ratios for the surface layer were $15.8 \pm 2.1$ in winter, $13.9 \pm 0.5$ in spring, $10.8 \pm 0.2$ in summer and $13.5 \pm 0.3$ in autumn (Table 3 ). In contrast, the molar ratio of nitrogen oxidised per carbon fixed by the nitrite oxidisers globally increased in summer $(21.8 \pm$ 4.4 in winter, $28.1 \pm 2.1$ in spring, $29.9 \pm 2.9$ in summer and $28.9 \pm 0.3$ in autumn) and showed high variability.

\section{DISCUSSION}

\section{Environmental factors controlling the nitrification rates}

Nitrification rates were independent of the geographical position of the sampling station, the depth of sampling and the season (Table 4). The salinity value 
Fig. 5. Spatio-temporal fluctuations of ammonium oxidation and nitrite oxidation rates
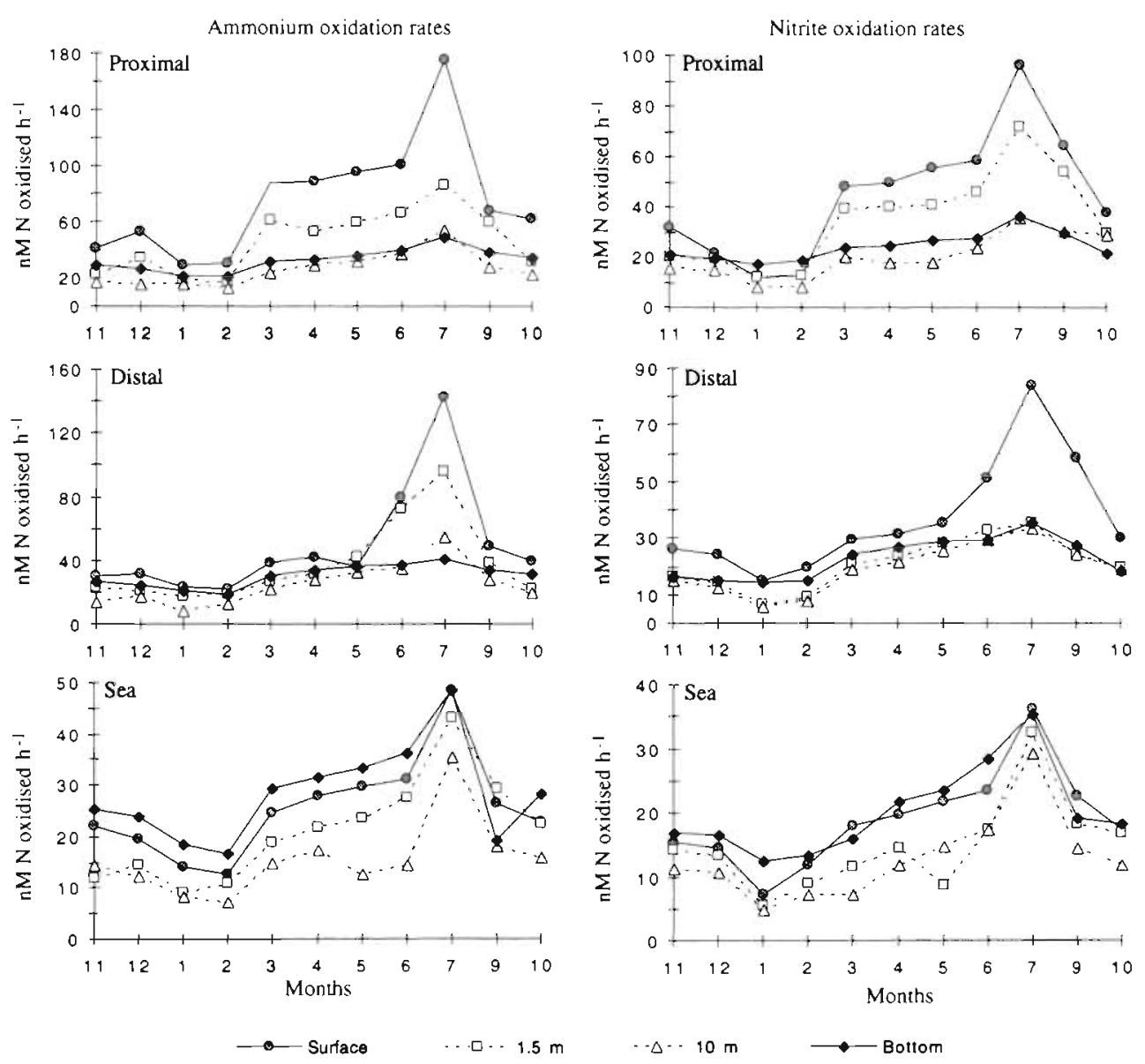

rather than the location of the sampling point drove spatial distribution of nitrification rates. The highest rates of nitrification were related to the lowest salinity, indicating that nitrification in the plume was supported by riverine inputs of $\mathrm{NH}_{4}{ }^{+}$. No linear or exponential decrease with depth of the nitrifying rates was observed.

The first step of nitrification, i.e. AO, was principally driven by the availability of substrates, irrespective of other environmental conditions (Fig. $7 \mathrm{a}$ ). $\mathrm{AO}$, in the present study, was regulated by the in situ ammonium concentration $\left(r^{2}=0.741, p=0.001, n=132\right)$. The importance of substrate availability to $\mathrm{AO}$ and $\mathrm{NO}$ rates has been described previously in the Antarctic Ocean (Bianchi et al. 1997). NO rate was regulated by the AO rate $\left(\mathrm{r}^{2}=0.850, \mathrm{p}=0.001, \mathrm{n}=132\right)$ independently of in situ nitrite concentration (Fig. 7b). Such control of the $\mathrm{NO}$ rates by the $\mathrm{AO}$ rates in the natural environment has been demonstrated for the first time in the present work. Indeed, the distribution of nitrogen salts in this estuarine area is due to the combination of the Rhône River inputs, the role of biological processes such as nitrification and denitrification (Bianchi et al. 1994) and/or primary production uptake (Bianchi et al. 1993).
From the large data set ( $\mathrm{n}=132$ ), a Model II regression was used to describe the mathematical relationship between $\mathrm{NH}_{4}^{+} / \mathrm{AO}\left(\mathrm{AO}\left[\mu \mathrm{M} \mathrm{h}^{-1}\right]=14.5+10 \mathrm{NH}_{4}^{+}[\mu \mathrm{M}]\right)$ and $\mathrm{AO} / \mathrm{NO}$ (nitrite oxidation $\left[\mu \mathrm{M} \mathrm{h}^{-1}\right]=4.7+0.56 \mathrm{am}$ monium oxidation $\left.\left[\mu \mathrm{M} \mathrm{h}^{-1}\right]\right)$. Such relationships could be used for modelling the biological processes (including the regulation of primary production).

The nitrification rates showed a highly significant relationship with temperature $\left(\mathrm{r}^{2}=0.247, \mathrm{p}=0.0001\right.$, $\mathrm{n}=132$ for $\mathrm{AO}$, and $\mathrm{r}^{2}=0.361, \mathrm{p}=0.0001, \mathrm{n}=132$ for $\mathrm{NO}) . Q_{10}$ values were determined for the temperature range 9 to $19.9^{\circ} \mathrm{C}$, corresponding to $5^{\circ} \mathrm{C}$ either side of in situ temperature. The $Q_{10}$ values have been calculated from the slope of the conventional Arrhenius plot (the logarithm of rate vs the absolute temperature) using the expression $Q_{10}=\exp \left(-10^{*} \mathrm{~m} / T_{15}{ }^{2}\right.$ ) (Raven \& Geider 1988), where $T_{15}$ is the in situ temperature (K) and $m$ is the slope of the line at in situ temperature. $Q_{10}$ values calculated from a large data set $(n=132)$ of in situ measurements were 2.72 for $\mathrm{AO}$ rates and 3.08 for NO rates. These values are close to the classical value of 2 for bacterial activities, but far from the apparent $Q_{10}$ of 17.6 (in situ data) or 7.5 (experiments) calculated by Berounsky \& Nixon (1990) in Narragansett Bay. 
nmole $\mathrm{CO}_{2}$ fixed $\mathrm{dm}^{-3} \mathrm{~h}^{-1}$ by Ammonium oxidisers

nmole $\mathrm{CO}_{2}$ fixed $\mathrm{dm}^{-3} \mathrm{~h}^{-1}$

by Nitrite oxidisers

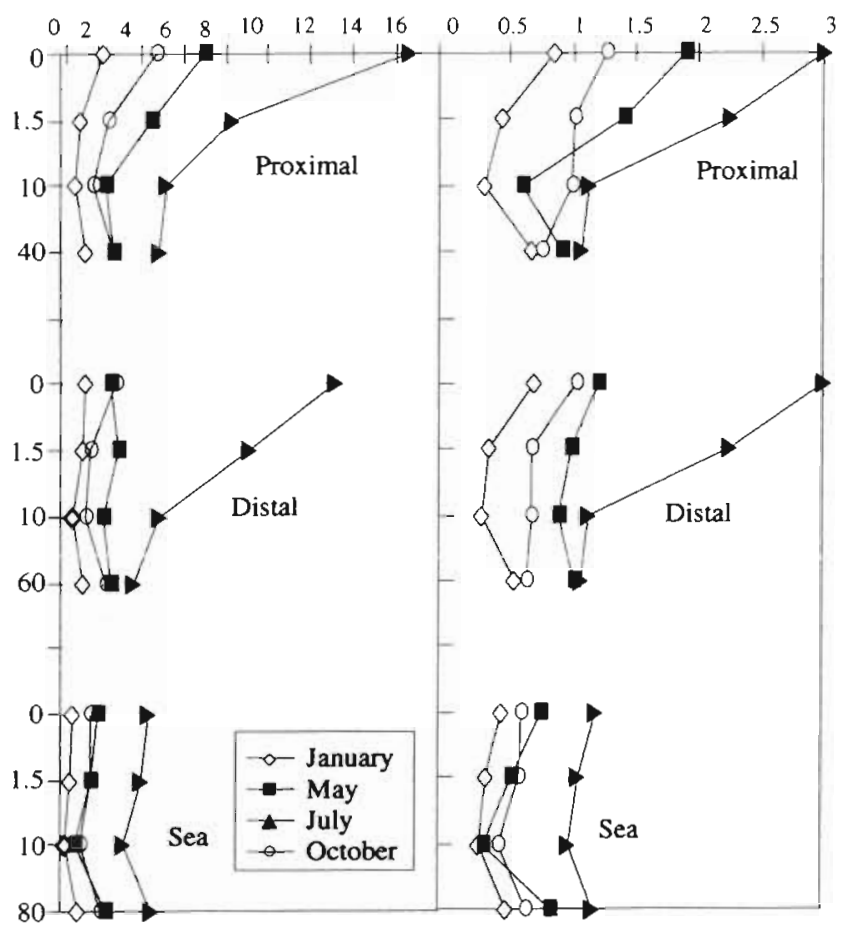

Fig. 6. Spatio-temporal fluctuations of carbon fixation rates of ammonium oxidising and nitrite oxidising bacteria

These authors used a fixed $\mathrm{N}$ oxidised to $\mathrm{C}$ incorporated ratio of 5.95 to extrapolate the NO rate from the $\mathrm{C}$ fixation rate, as they calculated the nitrification rates from the rates of ${ }^{14} \mathrm{C}-\mathrm{CO}_{2}$ incorporation. We have illustrated the spatial and seasonal variability of this ratio (Feliatra \& Bianchi 1993 and the present work), which should be taken into account for $Q_{10}$ calculations. If the values we measured were in the range of ammonium oxidising strains (reviewed in Ward 1986), the low summer values should imply that the biomass of these nitrifiers is mainly accumulated in summer. Using pure cultures of nitrifying bacteria (i.e. Nitrosococcus oceanus for $\mathrm{AO}$ and Nitrococcus mobilis for NO), Glover (1985) showed that the stoichiometric relationship between $\mathrm{NH}_{4}{ }^{+}$or $\mathrm{NO}_{2}{ }^{-}$oxidation and the yield of organic $\mathrm{C}$ production did not remain constant and appeared to be dependent on the availability of the inorganic substrate for oxidation. This was true for ammonium oxidisers, for which $\mathrm{C}$ fixation rates were highest in July when ammonium concentrations peaked, inducing high $\mathrm{AO}$ rates. But, the relationship between substrate and organic $C$ production was less clear for the nitrite oxidiser N. mobilis (Glover 1985). Considering the biomass production by nitrifiers in the study area, nitrite oxidisers displayed rates between 2 and 5 times lower than ammonium oxidisers, which could be explained by the fact that $\mathrm{NH}_{4}{ }^{+}$oxidation liberates more free energy than $\mathrm{NO}_{2}$ oxidation for an equivalent amount of $\mathrm{C}-\mathrm{CO}_{2}$ assimilation (Kelly 1978). However, in our measurements, $\mathrm{AO}$ as well as NO rates were positively correlated with temperature, while $\mathrm{C}-\mathrm{CO}_{2}$ fixation rates were positively correlated with temperature for ammonium oxidisers and negatively correlated with temperature for nitrite oxidisers, leading to a trend for the NO/C fixation ratio to increase during summer whatever the enhancement of NO rates (Fig. 8). In the Indian sector of the Southern Ocean, displaying low but measurable concentrations of ammonium (0.3 to $0.7 \mu \mathrm{M}$ ), the $\mathrm{NO} / \mathrm{C}$ fixation ratio for ammonium and nitrite oxidisers showed significant negative correlation with temperature (Bianchi et al. 1997), as did the ratio for ammonium oxidisers in the Rhône River plume.

Due to the difficulty in selective counting of bacteria in natural environments, few data are available concerning the numbers of marine nitrifying bacteria (see review in Ward 1986). Despite the development of molecular probes, it is difficult to assess the actual number
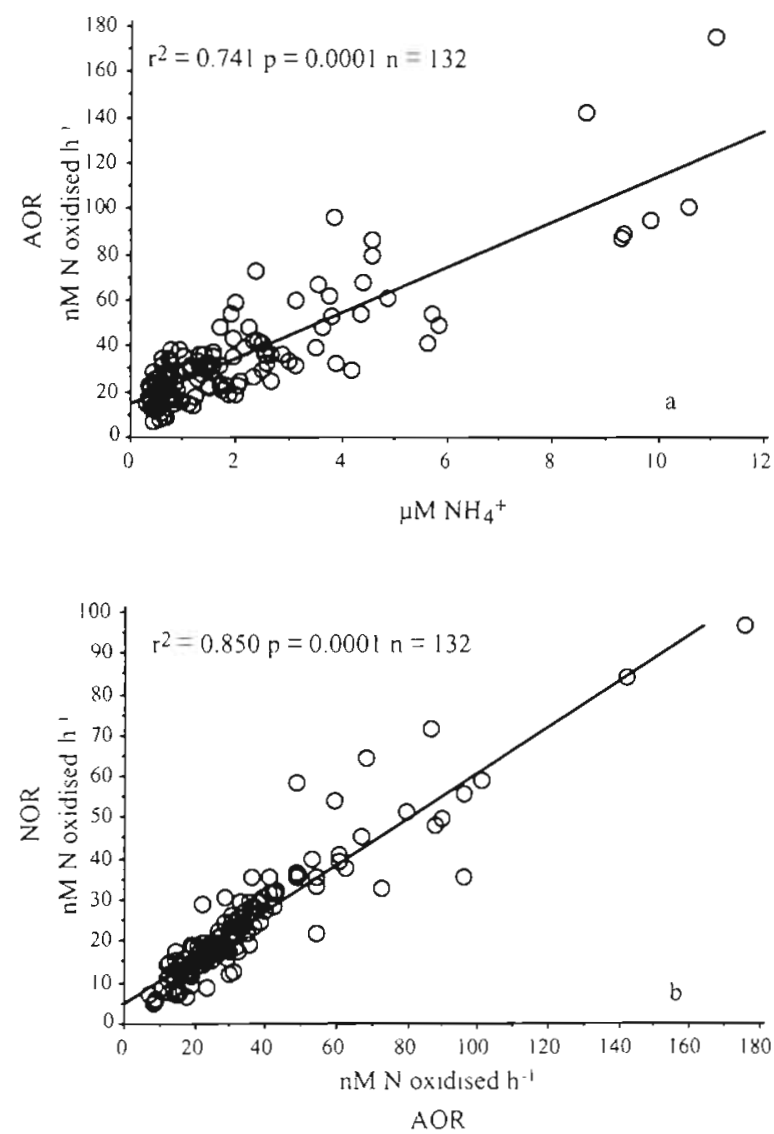

Fig. 7. (a) Correlation between ammonium oxidation rate (AOR) and in situ concentration of $\mathrm{NH}_{4}{ }^{*}$ (b) Correlation between nitrite oxidation rate (NOR) and $A O R$ 
of these bacteria in field samples (Ward 1995). Using the MPN technique, we were able to estimate that numbers of culturable nitrifiers in the Rhône River plume area were in the range of values reported in the literature (Ward 1995). The number of both nitrifiers increased in summer, concomitantly with the increase of the total number of bacteria. The average percentage of nitrifiers was less than $2 \%$ of the total counts. Counts of ammonium oxidisers were performed using nucleic probes at the same stations in this plume area, and showed the number of nitrifiers to be about 1 order of magnitude (Fosset 1998) higher than MPN counts. This discrepancy between 'total' and 'viable' counts could be in part explained by the contribution of non culturable bacteria to the total count. Nevertheless, the biomass production $\left(\mathrm{CO}_{2}\right.$ fixation rate) was well correlated with the living biomass increase (MPN numbers), i.e. $r^{2}=0.69, p=0.0001$ and $r^{2}=0.64, p=0.0001$, for ammonium and nitrite oxidisers, respectively. This indirectly validates the MPN method through an independent approach.

Nitrifying (AO and NO rates) activities were also well correlated with the number of corresponding culturable nitrifiers, independent of the spatio-temporal fluctuations. Thus, for ammonium oxidiser numbers and $\mathrm{AO}$ rates, $\mathrm{r}^{2}$ values ranged between 0.89 in winter and 0.96 in summer and autumn. For nitrite oxidiser numbers and NO rates, $\mathrm{r}^{2}$ values were 0.91 in spring and 0.99 in winter. Specific activities, calculated from the number of culturable nitrifiers obtained with the MPN method, fluctuated from 1.2 to $1.9 \times 10^{-15} \mathrm{~mol} \mathrm{~N}$ $\mathrm{NH}_{4}{ }^{+}$oxidised $\mathrm{d}^{-1}$ for ammonium oxidisers. These rates were relatively low compared to the nitrite production

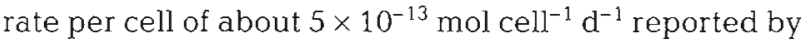
Ward et al. (1982) using immunofluorescent enumeration of the species Nitrosomonas marinus and Nitrosococcus oceanus. However, Ward et al. (1982) counted only 2 species of nitrifiers without knowing their relative importance within the overall ammonium oxidiser population in natural marine environments. For a pure culture and at its maximum growth rate $N$. oceanus demonstrated a per cell rate of $1.4 \times 10^{-12} \mathrm{~mol} \mathrm{cell}^{-1} \mathrm{~d}^{-1}$ oxidised (Carlucci \& Strickland 1968). It seems reasonable that natural rates would be lower than this value as the optimal conditions of growth may not exist in a marine environment. On the other hand, the activity per cell increased from the proximal to the sea station, showing an increase of specific activity in low substrate concentration conditions. Such modification of bacterial activity should be related to the lowering of substrate affinity $(\mathrm{Km})$ values in low nutrient environments, like that noted by Gentilhomme (1992) in the Southwestern Mediterranean Sea.

To summarise the control of nitrification in the estuarine environment, our data demonstrate that the rates

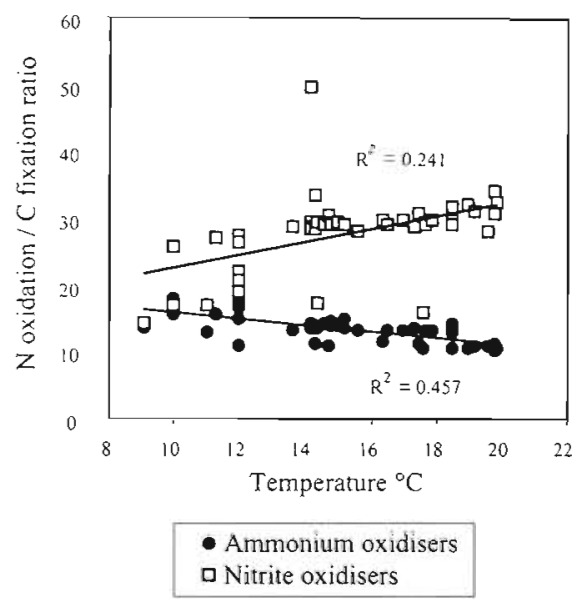

Fig. 8. Correlation between $\mathrm{N}$ oxidation/C fixation ratio and temperature for ammonium and nitrite oxidisers

of both $\mathrm{AO}$ and $\mathrm{NO}$ processes are mainly regulated by substrate concentration, the temperature being able to enhance or to reduce the resulting activity. The temperature increased the biomass production of both nitrifiers in summer, but it was less visible for nitrite oxidisers because $\mathrm{C}$ fixation rates showed a maximum increase (proximal and distal station in July) of 3 times while the NO rate increased by 5 times during the same period. The numbers of culturable nitrifiers were well correlated with their respective activities and the specific activity fluctuated in relation to the environmental concentration of substrate.

\section{Implication of nitrification in the oligotrophic marine area of the Rhône River plume}

In this estuary, we have seen that the behaviour of nitrification rates was clearly different in the water column and in the benthic nepheloid layer. So, the role of nitrification can be considered within each of these components of the estuarine area.

In the water column (surface and $1.5 \mathrm{~m}$ depth), for each month, we calculated, at the distal station, the difference between the concentrations of ammonium and nitrate measured in situ and those estimated from a conservative dilution as a function of the salinity (Fig. 9). The calculations took into account the concentration recorded at the mouth of the river on the same day, avoiding the possible seasonal influence of the river discharge. Positive values indicated a net source and negative values a net sink of ammonium and/or nitrate during the transit of the water from the river mouth to the edge of the plume. In winter, we observed a maximum of nitrate consumption despite the highest discharge rate (Coste et al. 1985). Previ- 


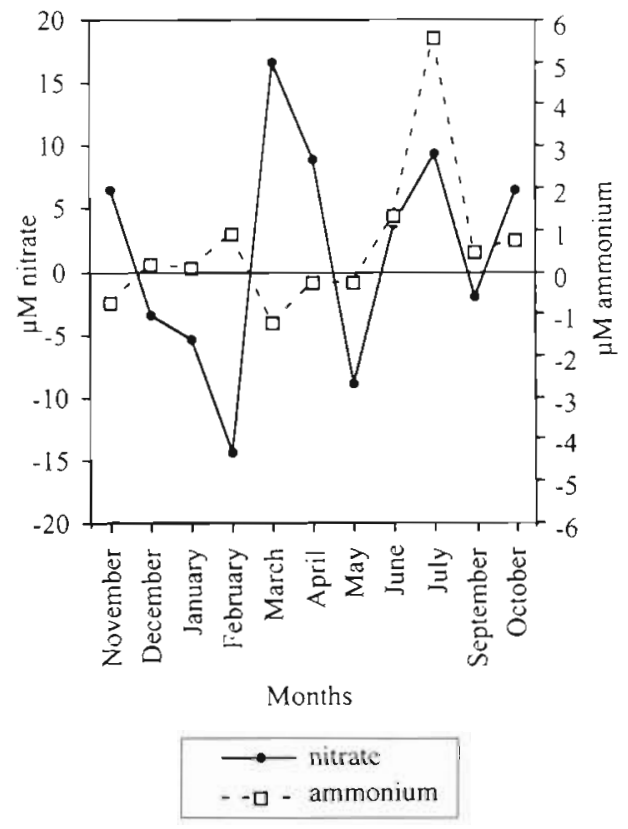

Fig. 9. Seasonal fluctuations of $\left(\mathrm{NO}_{3}{ }^{-}-\mathrm{NH}_{4}{ }^{+}\right)$departure from the salinity dilution line at the distal station. Positive values indicate a net source and negative values a net sink of $\mathrm{NH}_{4}{ }^{+}$ and $\mathrm{NO}_{3}{ }^{-}$

ous studies at same station highlight a cyanobacterial bloom during the winter period (Soto et al. 1993), which could be held responsible for the nitrate consumption. The second period of consumption, in May, is due to the spring bloom composed of large phytoplanktonic cells and autotrophic flagellates that peaked at the distal station (Soto et al. 1993). From March, nitrification increases (Fig. 5), which gives rise to the nitrate production before the spring bloom. This nitrate production (about $1.5 \mu \mathrm{M} \mathrm{d}^{-1}$ ) continues over the spring period, compensating in part for the nitrate consumption in May (Fig. 9). While ammonium concentration is close to the value given by the theoretical dilution in winter and spring, enhanced ammonium production is noted in June and July. This production may originate from biological processes; either from mineralisation of the organic matter delivered from the river or from the primary production in the plume (Coste et al. 1985, Soto et al. 1993, and as noted by Pakulski et al. 1995 in the Mississippi River plume) or by dissimilative reduction of the nitrate (Bianchi et al. 1994). At the same time, an excess of nitrate (Fig. 9) corresponds to the maximum of nitrification rate (Fig. 5).

In the bottom nepheloid layer, the load of suspended matter was always higher than in the water column, despite inputs from the Rhone River in the surface layer at the proximal station. In the bottom nepheloid layer, nitrification did not vary spatially.
Rates were low at all stations and throughout the year, reflecting the constant composition of particulate material in the benthic nepheloid layer in this area. The benthic nepheloid layer is enriched with organo-mineral aggregations linked to primary productivity (Aloisi et al. 1982). In fact, the particulate matter of the bottom nepheloid layer is a mixing of 'fresh' river inputs, and 'old' river inputs. The latter remains on the wide continental shelf of the Gulf of Lion for a period of time, allowing a 'homogenisation' of the composition of this material after mineralisation (S. Heussner pers. comm.). This homogenisation of particulate material is confirmed by a POC/PON ratio around 11 and by similar concentrations of inorganic nitrogen at all stations and throughout the year. Thus, the production of ammonium from this particulate material is levelled whatever the space and time distribution. In contrast to processes associated with the water column, nitrification rates in the benthic nepheloid layer displayed an independent distribution: (1) rates decreased very slowly from the river mouth to the sea, and (2) the surface/bottom rate ratio was about 2 at the proximal to less than 1 at the sea station, exhibiting an increasing contribution of the nitrification of this layer to the functioning of the ecosystem.

Average nitrification rates and corresponding ammonium concentration have been used to estimate that $10 \%$ and $20 \%$ of the ammonium, respectively, for winter and summer was nitrified at the river mouth. The nitrification peak is located at the edge of the plume corresponding to the region of intense nitrification as measured by Pakulski et al. (1995) at intermediate salinity of the Mississippi River plume. The nitrate produced by nitrification was estimated to be 292, 237 and $156 \mu \mathrm{M} \mathrm{yr}^{-1}$ for proximal, distal and sea stations respectively. In the Rhône River estuary, influence of river inputs, combined with the hydrodynamical and meteorological conditions, stimulates primary production at the edge of the plume. Applying the Redfield ratio $(\mathrm{C} / \mathrm{N}=106 / 16)$ to the primary production measured by Bianchi et al. (1993) in the proximal (73 $\mathrm{mg} \mathrm{C} \mathrm{m}^{-3} \mathrm{~d}^{-1}$ ), distal $\left(720 \mathrm{mg} \mathrm{C} \mathrm{m} \mathrm{m}^{-3} \mathrm{~d}^{-1}\right.$ ) and sea stations $(100 \mathrm{mg} C$ $\mathrm{m}^{-3} \mathrm{~d}^{-1}$ ), nitrogen requirements for primary production

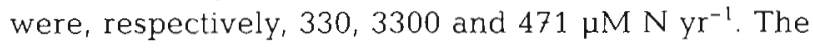
estimated contribution of the nitrification to the $\mathrm{N}$ requirement of primary producers was $14 \%$ at the distal station and $66 \%$ at the sea station independent of in situ nitrate concentrations. On the other hand, the nitrification contribution to the $N$ demand in the surface layer, in the NW Mediterranean, ranged from $16 \%$ to $61 \%$ for eutrophic to mesotrophic environments respectively (Bianchi et al. 1998a). Whether a coastal or an open ocean ecosystem, pelagic nitrification plays an important role in the nitrogen budgets and fluxes in the NW Mediterranean Sea. 


\section{LITERATURE CITED}

Aloïsi JC, Cambon JP, Carbone J, Cauwet G, Millot C Monaco A, Paul H (1982) Origine et rôle du néphéloïde profond dans le transfert des particules au milieu marin, application au Golfe du Lion. Oceanol Acta 5:481-491

Bendschneider K, Robinson RJ (1952) A new spectrophotometric method for the determination of nitrite in seawater J Mar Res 11:87-96

Berounsky VM. Nixon SW (1990) Temperature and the annual cycle of nitrification in waters of Narragansett Bay. Limnol Oceanogr 35:1610-1616

Bianchi M, Gaudy R, Goutx M, Leveau M, Lochet F, Pagano M, Soto-Mercado Y, Videau C (1993) Trophic relationships between pelagic components of a mesoscale front: the Rhône River plume front ecosystem. Ann Inst Océanogr Paris 69:57-62

Bianchi M, Feliatra, Bonin P (1994) Bacterial nitrification and denitrification rates in the Rhône River plume (northwestern Mediterranean Sea). Mar Ecol Prog Ser 103:197-202

Bianchi M, Feliatra, Tréquer P, Vicendeau MA, Morvan J (1997) Nitrification rates, ammonium and nitrate distribution in upper layers of the water column and in sediments of the Indian sector of the Southern Ocean. Deep-Sea Res $44: 1017-1032$

Bianchi M. Fosset C, Conan P (1999) Nitrification rates in the NW Mediterranean Sea. Aquat Microb Ecol 17:267-278

Bronk DA, Glibert PM (1993) Contrasting patterns of dissolved organic nitrogen release by two size fractions of estuarine plankton during a period of rapid $\mathrm{NH}_{4}{ }^{+}$consumption and $\mathrm{NO}_{2}^{-}$production. Mar Ecol Prog Ser 96 291-299

Carlucci AF, Strickland JDH (1968) The isolation, purification and some kinetic studies of marine nitrifying bacteria J Exp Mar Biol Ecol 2:156-166

Coste B (1993) Les apports en phosphore et en azote du Rhône au bassin Méditerranéen. Evolution au cours des 20 dernières années. 4èmes rencontres de l'Agence Régionale pour l'Environnement Provence-Alpes, Côte d'Azur, p 68-72

Coste B, Cadenes A, Minas HJ (1985) L'impact des apports rhodaniens en éléments nutritifs sur les eaux du golfe du Lion. Rapp P-V Réun Commn Int Explor Scient Mer Méditerr 29:53-55

Elkins JW, Wofsy SC, McElroy MB, Kaplan WA (1981) Nitrification and production of $\mathrm{N}_{2} \mathrm{O}$ in the Potomac: evidence for variability. In: Neilson BJ, Cronin LE (eds) Estuaries and nutrients. Humana Press, Clifton, NJ, p 447-464

Feliatra (1994) L'activité des bactéries nitrifiantes dans l'aire marine du panache rhodanien et dans l'eau et le sédiment de l'Océan Austral (Mission Antares 1). Thèse, Université Aix-Marseille II

Feliatra, Bianchi M (1993) Rates of nitrification and carbon uptake in the Rhône River plume (Northwestern Mediterranean Sea). Microb Ecol 26:21-28

Fosset C (1998) Activités et distribution des bactéries nitrifiantes dans le bassin Nord Occidental de la Mer Méditerranée. Thèse, Université de la Méditerranée, Marseille

Gentilhomme V (1992) Quantification des flux d'absorption et de régénération de l'azote minéral (nitrate, nitrite et ammonium) et organique (urée) dans la couche euphotique des océans oligotrophes. Thèse de doctorat, Université Aix-Marseille II

Glover HE (1985) The relationship between inorganic nitrogen oxidation and organic carbon production in batch and chemostat cultures of marine nitrifying bacteria. Arch Microbiol 142:45-50
Guerrero M, Jones R (1997) Light-induced absorbance changes associated with photoinhibition and pigment in nitrifying bacteria. Aquat Microb Ecol 13:233-239

Hall GH (1984) Measurement of nitrification rates in lake sediment: comparison of the nitrification inhibitors nitrapyrin and allythiourea. Microb Ecol 10:25-36

Helder W, de Vries RPT (1983) Estuarine nitrite maxima and nitrifying bacteria (Ems-Dollard estuary). Neth $J$ Sea Res $17: 1-18$

Johnstone BH, Jones RD (1988) Effects of light and CO on the survival of a marine-oxidizing bacterium during energy source deprivation. Appl Environ Microbiol 54: $2890-2893$

Kaplan WA (1983) Nitrification. In: Carpenter EJ, Capone DG (eds) Nitrogen in the marine environment. Academic Press, New York, p 139-190

Kelly DP (1978) Bioenergetics of chemolithotrophic bacteria. In: Bull AT, Meadow PM (eds) Companions to microbiology. Selected topics for further study. Longman, London, p 363-385

Lohrenz SE, Dagg MJ, Whitledge TE (1990) Enhanced primary production at the plume/oceanic interface of the Mississippi River. Cont Shelt Res 7:639-664

Minas M, Minas HJ (1989) Primary production in the Gulf of Lions with considerations to the Rhône river plume. Water Pollut Res Rept 13:112-12

Owens NJK (1986) Estuarine nitrification: naturally occurring fluidized bed reaction. Estuar Coast Shelf Sci 22:31-44

Pakulski JD, Benner R, Amon R, Eadie B, Whitledge T (1995) Community metabolism and nutrient cycling in the Mississippi River plume: evidence for intense nitrification at intermediate salinity. Mar Ecol Prog Ser 117:207-218

Porter KG, Feig YC (1980) The use of DAPI for identifying and counting aquatic microflora. Limnol Oceanogr 25:943-948

Prosser JI (1989) Autotrophic nitrification in bacteria. Adv Microb Physiol 30:125-181

Rand MC, Greenberg AE, Taras MJ, Franson MA (1979) Standard methods for the examination of water and wastewater, 14th edn. American Public Health Association, Washington

Raven JA, Geider RJ (1988) Temperature and algal growth. New Phytol 110:441-461

Solorzano L (1969) Determination of ammonium in natural waters by phenol hypochlorite method. Limnol Oceanogr 14:799-801

Somville M (1984) Use of nitrifying activity measurements for describing the effect of salinity on nitrification in the Scheldt estuary. Appl Environ Microbiol 47:424-426

Soto Y, Bianchi M, Martinez J, Vives-Rego J (1993) Seasonal evolution of microplanktonic communities in the estuarine front ecosystem of the Rhone River plume (NW Mediterranean). Estuar Coast Mar Sci 37:1-13

Strickland TJDH, Parsons TR (1972) A practical handbook of seawater analysis, 2nd edn. Fish Res Board, Ottawa

Tanaka H, Hayashi K, Sugahara I, Kimura T ( 1979) Studies on nitrification in beach sand. Bull Fac Fish Univ Mie 6:181-198

Tréguer P, Le Corre P (1975) Manuel d'analyse des sels nutritifs dans l'eau de mer (utilisation de l'Autoanalyzer II Technicon), 2ème édn. Université de Bretagne Occidentale, Brest

Van Wambeke F (1988) Numération et taille des bactéries planctoniques au moyen de l'analyse d'image couplée à l'épifluorescence. Res Microbiol 139:261-272

Videau C, Leveau M (1990) Biomasse et production phyto planctoniques dans le front du panache rhodanien. Situation printanière. CR Acad Sci (Paris) 311(III): 219-224 
Ward BB (1986) Nitrification in marine environments. In: Prosser JI (ed) Nitrification. IRL Press, Oxford, p $157-184$

Ward BB (1995) Functional and taxonomic probes for bacteria in the nitrogen cycle. In: Joint I (ed) Molecular ecology of

Editorial responsibility: John Dolan,

Villefranche-sur-Mer, France aquatic microbes. NATO ASI Series. Springer Verlag, Berlin, p 73-86

Ward BB, Olson RJ, Perry MJ (1982) Microbial nitrification rates in the primary nitrite maximum of Southern California. Deep-Sea Res 29:247-255

Submitted: April 8, 1998; Accepted: February 15, 1999 Proofs received from author(s): August 5, 1999 